\title{
Parental Involvement as a Important Factor for Successful Education
}

MAŠA ĐURIŠIĆ ${ }^{* 1}$ AND Mila BuniJEVAC ${ }^{2}$

$\approx$ To comply with the system of integrated support for their students', schools need to build partnership with parents and develop mutual responsibility for childrens' success in the educational system. In this way, parental involement are increased, parents' effort to support schools are encouraged, and they are directly making a positive impact to a successful educational system.

Considering the importance of parents' participation and involvement in school activities, in this paper, we will analyse the positive effects of parental involvement, summarize leading principles for the successful partnership of parents and school and present six factors (Parenting, Communicating, Volunteering, Learning at home, Decision-making and Collaborating with the community) and six models (Protective Model, Expert Model, Transmission Model, Curriculum-Enrichment Model, Consumer Model and Partnership Model) of parental involvement. In addition, we will draw conclusions and make recommendations that are important for planning programs that are focused on the improvement of parent involvement.

Keywords: parents' involement, successful education, school-family partnership, examples of good practice

1 *Corresponding Author. Primary school „Veselin Masleša“ Belgrade, Serbia; masa_jovanovic85@ yahoo.com.

2 Clinical Hospital “St. Sorcerers" in Bijeljina, Bosnia and Herzegovina. 


\section{Vključevanje staršev kot pomemben dejavnik uspešnega izobraževanja}

Maša Đurišić in Mila BuniJEVAC

$\propto$ Skladno s celostno podporo učencem morajo šole vzpostavljati partnerstvo s starši in razvijati skupno odgovornost za uspeh otrok v šoli. Tako povečujemo vključevanje staršev, spodbujamo starševsko podporo šoli in neposredno pozitivno vplivamo na uspešnost vzgojnoizobraževalnega sistema. Upoštevajoč pomembnost sodelovanja in vključevanja staršev v šolske dejavnosti, v tem prispevku analiziramo pozitivne učinke vključevanja staršev, povzemamo vodilna načela za uspešno sodelovanje staršev in šol ter predstavljamo šest dejavnikov (starševska vloga, komunikacija, prostovoljstvo, domače učenje, sprejemanje odločitev in sodelovanje s skupnostjo) in šest modelov vključevanja staršev (zaščitniški model, ekspertni model, transmisijski model, model obogatitve kurikuluma, potrošniški model in partnerski model). Poleg tega oblikujemo sklepe in priporočila, pomembna za načrtovanje programov, ki so usmerjeni $\mathrm{k}$ izboljšanju vključevanja staršev.

Ključne besede: vključevanje staršev, uspešno izobraževanje, partnerstvo šol in staršev, primeri dobre prakse 


\section{Introduction}

Many researchers recognise the important role that strong positive bond between homes and schools, play in the development and education of children (Edwards \& Alldred, 2000; Henderson \& Berla, 1994; Richardson, 2009; Sanders \& Sheldon, 2009; Sheldon, 2009). The theories put forward have been supported, and reaffirmed, by numerous studies that have shown that good cooperation between schools, homes and the communities can lead to academic achievement for students, as well as to reforms in education. Research has also shown that successful students' have strong academic support from their involved parents (Sheldon, 2009). Furthermore, research on effective schools, those where students are learning and achieving, has consistently shown that these schools despite often working in low social and economic neighborhoods, have strong and positive school-home relationships (Sanders \& Sheldon, 2009; Sheldon, 2009). More importantly, these effective schools with positive school climate, have made a real effort in reaching out to their students' families in order to bring about good cooperation. Sanders and Sheldon (2009) maintain that schools become successful when a strong and positive relationship among students, parents, teachers and the community has been established. All students' are more likely to experience academic success if their home environment is supportive (Henderson \& Berla, 1994; Sanders \& Sheldon, 2009).

Epstein (2001, 2009) alleges that there are many reasons for developing and establishing a partnership between school, family and community. The main reason for such a partnership is to aid students in succeeding at school. Other reasonsinclude improvinge school climate and school programs, developing parental skills and leadership, assisting families in connecting with others in the school and the community, and assisting teachers with their work. All these reasons emphasise the importance of parents playing an active role in their childrens' education and keeping a strong and positive relationship with schools.

\section{Models of parental involvement}

Educators and parents play major roles in the educational success of students. Students need a positive learning experience to succeed in school: one providing support, motivation, and quality instruction. With the increasing demands on the family, parental support in the education of students extends beyond the school building. Many families are faced with overwhelming and unpredictable schedules and circumstances while juggling school, sports, 
family situations, family time, work schedules, and other responsibilities, allowing minimal time to provide support in any one given area (Swap, 1993).

Although it seems that parental involvement is researched the topic of many domestic and foreign studies, there is still concern regarding parental involvement and what constitutes effective parental involvement in the education of students. Educators, parents, and community members may have different opinions regarding effective involvement practices and the ways each can contribute to the educational process.

Parental involvement in the education of students begins at home with the parents providing a safe and healthy environment, appropriate learning experiences, support, and a positive attitude about school. Several studies indicate increased academic achievement with students that have involved parents (Epstein, 2009; Greenwood \& Hickman, 1991; Henderson \& Berla, 1994; Rumberger et al., 1990; Swap, 1993; Whitaker \& Fiore, 2001). Studies also indicate that parental involvement is most effective when viewed as a partnership between educators and parents (Davies, 1996; Emeagwali, 2009; Epstein, 2009). By examining parents' and teachers' perceptions, educators and parents should have a better understanding of effective parental involvement practices in promoting student achievement.

Numerous researchers such as Berger (2008), Davies (1996), Epstein (2009), and Henderson and Mapp (2002) have studied parental involvement and its effects on the educational process over the years. A leading researcher of parental involvement is Joyce Epstein, the founder and director of the National Network of Partnership Schools at Johns Hopkins University. With numerous studies and work in over 100 publications, Epstein focuses on school, family, and community partnership programmes that will improve policy and practice in an effort to increase student academic achievement and student success. Epstein has identified a framework wich containing six important factors with regards to parental involvement. This framework is based on findings from many studies of what factors are most effective with regards comes to childrens education (Epstein, 1995, 1996, 2001, 2003, 2009). Those six factors are parenting, communicating, volunteering, learning at home, decision-making and collaborating with the community.

Parenting - includes all of the activities that parents engage in to raise happy, healthy children who become capable students. Unlike teachers, whose influence on a child's is relatively limited, parents maintain a life-long commitment to their children. Activities that support this type of involvement provide information to parents about their child's development, health, safety, or home conditions that can support student learning. Includes: parent education and 
other courses or training for parents, family support programmes to assist families with health, nutrition, and other services, home visits at transition points to elementary, middle, and secondery school.

Communicating - Familes and schools communicate with each other in multiple ways. Schools send home notes and flyers about important events and activities. Parents give teachers information about their child's health and educational history. A school website is an additional mode of communication with parents and families. Includes: conferences with every parent at least once a year, language translators to assist families as needed, regular schedule of useful notices, memos, phone calls, newsletters, and other communications.

Volunteering - applies to recruiting and organising help and support from parents for school programmes and students' activities. There are three basic ways that individuals volunteer in education. First, they may volunteer in the school or classroom by helping teachers and adminstrators as tutors or assistants. Second, they may volunteer for the school; for instance, fundraising for an event or promoting a school in the community. Finally, they may volunteer as a member of an audience, attending school programmes or performances. Includes: school/classroom volunteer programme to help teachers, administrators, students, and other parents, parent room or family center for volunteer work, meetings, and resources for families, annual postcard survey to identify all available talents, times, and locations of volunteers.

Learning at home - pertains to providing ideas and information to parents about how they can best assist their children with homework and curricular-related decisions and activities. Parents helping their children with homework or takeing them to a museum, are examples of this type of involvement. These activities produce a school-oriented family and encourage parents to interact with the school curriculum. Activities to encourage learning at home provide parents with information on what children are doing in the classroom and how to help them with homework. Includes: information for families on skills required for students in all subjects at each grade, information on homework policies and how to monitor and discuss schoolwork at home, as well as family participation in setting student goals each year and in planning for college or work.

Decision making - refers to including parents in school decisions and to developing parent leaders and representatives. Parents participate in school decision making when they become part of school governance committees or join organizations, such as the parent/teachers association. Other decisionmaking activities include taking on leadership roles that involve disseminating information to other parents. Includes: active PTA/PTO or other parent 
organizations, advisory councils, or committees for parent leadership and participation, independent advocacy groups to lobby for school reform and improvements, networks to link all families with parent representatives.

Collaborating with the community - pertains to identifying and integrating communities" services and resources to support and strengthen schools, students, and their families. Includes: information for students and families on community health, cultural, recreational, social support, and other programmes/services, information on community activities that link to learning skills and talents, including summer programmes for students.

Each of these factors can lead to various results for students, parents, teaching practices, and the school climate. In addition, each factor includes many different practices of partnership. Lastly, each factor poses challenges to involve all families and those challenges must be met. That is why Epstein (2001; 2009) considers it to be significant for each school to choose what factors are believed to be most likely to assist the school in reaching its goals for academic success, and to develop a climate of alliance between homes and the school. Even though the primary focus of these six factors is to promote academic achievements, they also contribute to various results for both parents and teachers (Epstein, 2003, 2009). For instance, it may be presumed that parents will gain more self-confidence in their role as parents, they will show leadership with decision-making, and they will have more effective and productive communication with their children with regards to school work, and will have more communication with other parents at the school. According to Henderson and Berla (1994), parents also gain a more positive attitude towards the school and its staff, and gain more confidence in assisting their children with homework, by being involved with their education. In addition, they are more likely to gather support for the school and its programmess in the community and become more active community members. For teachers, the benefits may be presumed to be better communication with parents, a deeper understanding of the family of their students and their situation, and more effective communication with both the homes and the community (Epstein, 2009). Henderson and Berla (1994) also claim that the schools will benefit from parental involvement by improved teacher morale, more support from families and higher student academic achievement. In addition, Clarke (2007) asserts that schools function best when parents and the community are active participants and have a sense of ownership of the school. Therefore, it is safe to say that these six factors not only benefit the students, but also their parents, teachers and schools. 


\section{Determinants of Parental Involvement}

Parents' cognitions about their role have been identified as a major contributor to their willingness to engage in supportive parenting. We focused on three forms of parental cognition: parents' aspirations concerning their children's future occupation, their self-efficacy in rearing and educating their children, and their perceptions of the school (Eccles \& Harold, 1996; HooverDempsey \& Sandler, 1997; Okagaki \& Frensch, 1998).

Parental Aspirations - Parental aspirations refer to idealistic hopes or goals that parents may form regarding future attainment. Parents who hold high aspirations for their children's future are likely to be more willing to exert efforts to ensure that those aspirations are realized. Indeed, evidence from research suggests that educational and occupational aspirations are associated with the ways in which parents shape children's activities, time, and learning environment (Murphey, 1992).

Parenting Self-Efficacy - The construct of self-efficacy refers to „beliefs in one's capabilities to organize and execute the courses of action required to produce given attainments" (Bandura, 1997, p. 3). Research conducted in a variety of countries finds that individuals with high self-efficacy in a specific area exert effort in that area, persevere in the face of difficulty, and respond resiliently to adversity (Bandura, 2002). They are less prone to self-defeating thought patterns, and they experience less stress and depression than those with lower self-efficacy. The construct of self-efficacy is intended to be domain specific; particular experiences with respect to a given domain affect the individual's sense of confidence about acting efficaciously in that domain.

The domain of parenting self-efficacy has been examined at length, and parenting self-efficacy has shown to be an extraordinarily powerful determinant of effective parenting behaviour in Western societies. Parents with high self-efficacy are generally more optimistic, authoritative, and consistent in their interactions with their children than those with lower parenting self-efficacy (Ardelt \& Eccles, 2001; Bandura, Barbaranelli, Caprara, \& Pastorelli, 1996; Olioff \& Aboud, 1991). Additionally, theoretical formulations have identified parenting self-efficacy as a key determinant of parental involvement in schooling (Eccles \& Harold, 1996; Hoover-Dempsey \& Sandler, 1997). Empirical work suggests that parents with high self-efficacy are more likely to monitor their children's schoolwork and to participate actively at the school (Ardelt \& Eccles, 2001).

Perceptions of the School - Parents' degree of involvement is likely to be affected by the school itself. If teachers appear to care about the welfare of the child, communicate respect for parents, and develop effective means of 
communicating with families, parents are more willing and able to become involved in their children's schooling (Hoover-Dempsey \& Sandler, 1997).

\section{Parental involvement: a summary of empirical findings}

Parents and families have a major impact on the success of the process of education and upbringing of children. Involvement of parents is related to their position at home (monitoring the learning of children), as well as participation in activities organized at school (parent-teacher conferences, volunteer activities, various forms of parental activism, workshops and seminars for parents). It is well established that parental involvement is correlated with school achievement of both children and adolescents (Long, 2007; Rich, 1987). Elementary school children gain greater academic, language, and social skills (Grolnick \& Slowiaczek, 1994), middle and high school students have greater achievement and future aspirations (Eccles \& Harold, 1993) and spend more time doing and completing homework (Epstein et al., 2009). Research shows that parental involvement is more important to children's academic success than their family's socioeconomic status, race, ethnicity, or educational background (Amatea \& West, 2007; Henderson \& Berla, 1994). Parental involvement can encourage children's and adolescents' achievement in many ways. One way that parents can contribute positively to their children's education is to assist them with their academic work at home. Parents who read to their children, assist them with their homework, and provide tutoring using resources provided by teachers tend to do better in school than children whose parents do not assist them (Ball \& Blachman, 1991; Izzo et al., 1999). Futhermore, research shows that the level of parental involvement is associated with academic success. Children whose parents are actively involved in their schooling benefit better than children whose parents are passively involved. Specifically, if parents attend teacher conferences, accept phone calls from the school, and read and sign messages from school, their children will benefit academically more than children whose parents do none of the above. Furthermore, children excel even more when their parents assist them at home with their homework, attend school sponsored events, and volunteer at their children's schools (Suizzo, 2007; Weisz, 1990).

\section{Barriers to parental involvement}

Although parental involvement is recognized as being of significance in the education of children, there remains great diversity concerning parental involvement. Some factors exist over which schools have little control and these 
factors have become of great interest to educational decision makers (Feurstein, 2000).

Today's parents are often preoccupied with the distractions and demands of daily life. Burdened by low-income, inflexible work hours and language barriers, some parents are unable to attend school activities or participate in the schooling of their children on a regular basis (Ho, 2009). Bæck (2010) as well as Lee and Bowen (2006) cite cultural norms, insufficient financial resources, and lack of educational attainment as barriers to parental involvement in school.

Davis (1996) found that many parents suffer from low self-esteem and others did not experience success in school themselves and therefore lack the knowledge and confidence to help their children. Parents who did not experience success in school may view it negatively (Greenwood \& Hickman, 1991). Parents may be intimidated by the language, the curriculum, and the staff; consequently they avoid communication with the school (Flynn, 2007).

Rutherford and Edgar (1999) recognize that parents have increased difficulty in being involved in their student's secondary education as determining which educator is responsible for which part of the child's academic programme can be overwhelming. Hill and Taylor (2004) assert that "parents from lower socioeconomic backgrounds face many more barriers to involvement, including nonflexible work schedules, lack of resources, transportation problems, and stress due to residing in disadvantaged neighborhoods" (2004, p. 162). Ascher (1988) reported that low-income urban parents can and want to participate in the education of their children as much as middle-class parents. She also reported that, single-parent participation is often hindered by inflexible leave policies and child-care responsibilities. Many school officials tend to decide in advance that single and low-income working parents can not be approached or relied upon. They are not expected to participate in their children's classroom, attend meetings, or provide assistance with home learning activities (Ascher, 1988).

Williams and Sanchez (2011) identify four areas that are barriers to involvement: time poverty, lack of access, lack of financial resources, and lack of awareness. Johnson (1994) asserted that "feelings of inadequacy, limited school background, or preoccupation with basic necessities may prevent parents from communicating with schools" (1994, p. 46). Lee and Bowen (2006) and Dika and Singh (2002) cite social capital in families as being positively linked to their students' achievement, graduation rates, higher educational attainment, as well as motivation and involvement in school. Similarly, Ho (2009) discusses the benefit of parents' involvement in schools, noting that it helps parents overcome a lack of social capital. Likewise, Hill and Taylor (2004) assert that 
parental involvement in the school supports students' achievement by increasing the parents' social capital.

Students are a critical component for successful school, family, and community involvement and can create a barrier for partnerships when they fail to fulfill their duty (Epstein, 1995). Students are often responsible for delivering information and communicating with their parents regarding school programmes, activities, and events (Epstein, 1995).

In programmes that require high level of involvement, teachers help students understand their role and the importance of actively participating in the family, school, and community partnership (Epstein, 1995). Given decreased budgeted funds in education and increased expectations, school administrators and teachers must take the initiative to involve parents in an effort to assist the educational achievement of students (Wherry, 2009). Some school administrators and teachers may not know how to involve parents; therefore, educators lacking this knowledge could be taught techniques for involving parents and creating partnerships (Greenwood \& Hickman, 1991). Administrators and teachers may not fully understand the importance of parental involvement and the effects of parental involvement on student achievement (Flynn, 2007).

Often, teachers believe parents do not support the school and do not discipline children when there has been a problem at school. When teachers do not feel parental support, they often believe it is a waste of their time to contact parents (Flynn, 2007).

To overcome the barriers preventing parental involvement, schools need to provide a welcoming climate where the school staff is respectful and responsive to parents (Wherry, 2009). It is critical that administrators and teachers encourage respectful two-way communication between the school and home (Wherry, 2009). Bouie, an educational consultant stated, “The answer is to stop treating parents like „clients” and start treating them like „partners” in helping children learn” (as cited in Wherry, 2009, p. 7). A survey of parents in four school systems concluded that parents want to be treated with respect and do not want a professional client relationship (Davies, 1991). Failure to sufficiently train preservice teachers is a significant obstacle in promoting parental involvement in the schools (Epstein, 1995). Preservice teachers could work with parents as part of their teacher education programme and internship (Greenwood \& Hickman, 1991). Classes could be incorporated into teacher education programmes and advanced degree programs to assist in defining an educator's role in school, family, and community partnerships (Epstein, 1995).

Some school systems have employed parent involvement coordinators to lead and coordinate parental involvement activities and programmes within 
the system in an effort to overcome obstacles between the home and school (Epstein, 2001). Epstein (2009) described the role of parent involvement coordinators as a way of encouraging more parents to become involved in a variety of aspects of the school. Parent involvement coordinators often conduct workshops for parents to inform them of the school curriculum and remind them that they are their child's most important teacher (Epstein, 2009).

\section{Adequately parent involvement: examples of good practice}

Considering the research findings, their own practical experience, as well as discussions with other experts, Bouffard and Weiss (2008) summarize some of the basic principles that the process of involving families can make meaningful and useful. First, the involvement of parents must be part of a broader strategy of complementary support learning and development as a systematic effort supported by joint action of all stakeholders. Furthermore, the involvement of parents should be viewed as a continuous process that has its evolutionary stages through childhood and adolescence, and is especially important in the periods of the transition of children from one to another level of schooling. However, not all parents have equal capacities for fuller participation in all activities and not all schools are interested and able adequately support participation in them. Research shows that the traditional system of parental participation, despite good intentions, usually leaves out the participation of non-dominant parents. In the modern school system, there is no generally accepted model of parental participation.

Analysing a number of existing approaches in establishing an adequate model of the relationship between parents and schools, Swap (1993) identifies three models of parental involvement.

Protective Model - the goal of this model is to avoid conflict between teachers and parents by keeping the teaching and parenting functions separate (Swap, 1993). It is referred to as the protective model because its objective is to protect the school from interference by parents. The teacher's responsibility is to educate children, while the parent's responsibility is to make sure children get to school on time with the correct supplies. In this model, parental involvement is seen as unnecessary and as potentially interfering with the education of children.

Transmission Model - is predicated on the view that teachers see themselves as the primary source of expertise on children but who recognize the benefits of using parents as a resource (Swap, 1993). In this model, the teacher 
remains in control and decides on the intervention, but does accepts that parents can play an important role in facilitating children's progress. Teachers using this approach must have additional skills, including techniques to effectively guide parents and interpersonal skills to establish productive working relationships. One drawback of this approach is the assumption that all parents can, and should, take on the role of acting as a resource (Swap, 1993). This model has the potential to overburden parents by placing excessive demands on them to carry out activities in the home.

Curriculum-enrichment Model - the goal of this model is to extend the school curriculum by incorporating parent's contributions (Swap, 1993). This model is based on the assumption that parents have valuable expertise to contribute and the interaction between parents and teachers will enhance the curriculum and the educational objectives of the school. Parent involvement in this model focuses primarily on curriculum and instruction within schools. The major drawback to this model is that it involves teachers permitting parents to have tremendous input regarded what is taught and how it is taught. In some cases, this may seem threatening to the teacher.

Ten years later, Hornby (2011) addes descriptions of three more models:

Expert Model - in this model teachers consider themselves to be the experts regarding all areas of the development and education of children, whereas parent's views are given little credence (Cunningham \& Davis, 1985). Teachers maintain control over all decisions, while the parent's role is to receive information and instruction about their children. Parent's views and feelings, the need for a mutual relationship, and the sharing of information are given little, if any, consideration.

Consumer Model - In this model, teachers function as more of a consultant while parents decide what action is to be taken (Cunningham \& Davis, 1985). The responsibility of decision-making lies on the shoulders of the parents, but it is the teachers' responsibility to provide parents with relevant information and the options available. In this model, teachers defer to the parents, who are placed in the expert role. Because parents are in control of the decision-making process, they are more likely to be satisfied with the services they receive, to feel more confident in their parenting, and to be less dependent on professionals.

Partnership Model - is the most appropriate model one in which teachers are considered to be experts on education and parents are viewed as experts on their children (Hornby, 2001).The goal is to establish a partnership in which teachers and parents share expertise and control in order to provide the optimum education for children, each contributing different strengths to 
the relationship. Mutual respect, long-term commitment to a wide range of activities, and sharing of planning and decision-making responsibilities are the essential components for true partnerships between parents and teachers are to occur.

The essence of effective partnerships between parents and school staff was summarized in seven principles by Turnbull and colleagues (2011). A key principle of effective partnership is trust. The teacher is required to have reliable, confidential, open and honest relationships with parents. Furthermore, the relationship must be based on mutual respect which means respect for the opinions of others and respect for the dignity of others. Parents should be convinced of the competence of persons who are professionally involved in the work with their children. Effective partnerships require two-way communication that will enable the exchange of knowledge and ideas between all parties involved. No less important is the imperative of protecting children, which is achieved through early identification of problems, their solution, the identification of appropriate strategies and the promotion of knowledge about the protection of children.

\section{Conclusion}

Research has indicated that great schools have effective partnerships with parents (Davies, 1996); therefore, school, family, and community partnerships are critical component in educating students.

Parental involvement provides an important opportunity for schools to enrich current school programmes by bringing parents into the educational process. Increased parental involvement has been shown to result in increased student success, enhanced parent and teacher satisfaction, and improved school climate. To ensure effective parental involvement, schools may have partnership programmes in place that continually develop, implement, evaluate, and improve plans and practices encouraging family and community involvement. Schools can encourage involvement in several of areas including parenting, learning at home, communication, volunteering, decision-making, and community collaboration. Effective parental involvement programmes are built upon a careful consideration of the unique needs of the community. In order to build trust, effective approaches to parent involvement rely upon a strengthbased approach, emphasizing positive interactions. Though specifics may vary, all parent involvement programs share the goal of increasing parentschool collaboration in order to promote healthy child development and safe school communities. 
There must be mutual trust and respect between the home, school, and community. Partnership programmes within the school can train volunteers on specific ways and strategies to assist in the classroom or school. With this type of training, all volunteers will know the expectations and have a better understanding of the operations of the school. Schools need to attempt to involve numerous parents and community members in the education of students through effective partnership programmes in an effort to express the importance of education. Finally, schools may implement involvement activities that concentrate on involving all parents. Administrators and educators must provide a welcoming and inviting atmosphere to make the school less intimidating and more comfortable for those parents who have negative experiences in the school. Interactions between the school and home need to be more positive, requiring teachers to contact families throughout the year and not just when problems arise. It is may be beneficial for administrators and educators to attempt to involve all parents in the education of their children and make the educational experience more positive for everyone involved.

\section{References}

Ascher, C. (1988). Improving the home-school connection for low-income urban parents. Urban Review, 20(1), 109-123.

Amatea, E. S., \& West, C. A. (2007). Joining the conversation about educating our poorest children: Emerging leadership roles for school counselors in high poverty schools. Professional School Counseling, 11(2), 81-89.

Ardelt, M., \& Eccles, J. S. (2001). Effects of mothers 'parental efficacy beliefs and promotive parenting strategies on inner-city youth. Journal of Family Issues, 22(8), 944-972.

Bæck, U. D. K. (2010). Parental involvement practices in formalized home-school cooperation. Scandinavian Journal of Educational Research, 54(6), 549-563.

Ball, E.W. \& Blachman, B.A. (1991). Does phoneme awareness training in kindergarten make a difference in early word recognition and developmental spelling? Reading Research Quarterly, 26(1), $49-66$.

Bandura, A. (1997). Self-efficacy: The exercise of control. New York: W.H. Freeman.

Bandura, A. (2002). Social cognitive theory in cultural context. Applied Psychology: An International Review, 51(2), 269-290.

Bandura, A., Barbaranelli, C., Caprara, G. V. \& Pastorelli, C. (1996). Multifaceted impact of selfefficacy beliefs on academic functioning. Child Development, 67(3), 1206-1222.

Berger, E.H. (2008). Parents as partners in education. Upper Saddle River, NJ: Pearson.

Bouffard, S. \& Weiss, H. (2008). Thinking big: A new framework for family involvement policy, practice, and research. The Evaluation Exchange, 14(1-2), 2-5. 
Clarke, A. (2007). The handbook of school management. Cape Town: Kate McCallum.

Cunningham, C., Davis, H. (1985). Working with Parents: Frameworks for Collaboration. Milton

Keynes: Open University Press.

Davies, D. (1991). Schools reaching out: Family, school, and community partnerships for student success. Phi Delta Kappan, 72(5), 376-380.

Davies, D. (1996). Partnerships for student success. New Schools, New Communities, 12(3), 13-21.

Dika, S. L., \& Singh, K. (2002). Applications of social capital in educational literature: A critical synthesis. Review of Educational Research, 72(1), 31-60.

Feuerstein, A. (2000). School characteristics and parent involvement: Influences on participationin children's schools. Journal of Educational Research, 94(2), 29-39.

Flynn, G. (2007). Increasing parental involvement in our schools: The need to overcome obstacles, promote critical behaviors, and provide teacher training. Journal of College Teaching \& Learning, 4(2), 23-30.

Edwards, E. \& Alldred, P. (2000). A typology of parental involvement in education centring on children and young people: negotiating familialisation, institutionalisation and individualization. British Journal of Sociology of Education, 21(3), 435-455.

Eccles, J.S. \& Harold, R.D. (1993). Parent-school involvement during the early adolescent years.

Teachers College Record, 94(3), 568-587.

Eccles, J. S., \& Harold, R. D. (1996). Family involvement in children's and adolescents's schooling. In A. Booth \& J. F. Dunn (Eds.), Family-school links: How do they affect educational outcomes? (pp. 3-34). Hillsdale, NJ: Erlbaum.

Emeagwali, S. (2009). Fostering parent-teacher collaboration in the classroom. Techniques (Association for Career and Technical Education), 84(5), 8.

Epstein, J. L. (1995). School, family, community partnerships: Caring for the children we share. Phi Delta Kappan, 77(9), 701-712.

Epstein, J. (1996). Perspectives and previews on research and policy for school, family, and community partnerships. In A. Booth \& J. Dunn (Eds.), Family-school links: How do they affect educational outcomes? (pp. 209-246). Mahwah, NJ: Erlbaum.

Epstein, J. (2001). School, family, and community partnerships: Preparing educators and improving schools. Boulder, CO: Westview.

Epstein, J. L., Sanders, M. G., Simon, B. S., Salinas, K. C., Jansorn, N. R., \& Van Voorhis, F. L. (2002). School, family, and community partnerships: Your handbook for action. (2nd ed.). Thousand Oaks, CA: Corwin.

Epstein, J. (2003). Creating school, family, and community partnerships. In A.C. Ornstein, L.S. Behar-Horenstein, \& E.F. Pajak (Eds.), Contemporary issues in curriculum. (3rd ed.) (pp. 354-373). Boston, MA: Allyn and Bacon.

Epstein, J.L. (2009). In School, family, and community partnerships: Your handbook for action (3rd ed.). USA: Corwin Press.

Greenwood, G. E., \& Hickman, C. W. (1991). Research and practice in parent involvement: 
Implications for teacher education. The Elementary School Journal, 91(3), 279-288.

Grolnick, W. S., \& Slowiaczek, J. L. (1994). Parental involvement in children's schooling: A

multidimensional conceptualization and motivational model. Child Development, 65(4), 237-252.

Henderson, A., \& Berla, N. (1994). A new generation of evidence: The family is critical to student achievement. Columbia, MD: National Committee for Citizens in Education.

Henderson, A., \& Mapp, K. L. (2002). A new wave of evidence: The impact of school, family, and community connections on student achievement. Annual synthesis. Austin, TX: National Center for Family and Community Connections with Schools, Southwest Educational Development Laboratory.

Hill, N. E., \& Taylor, L. C. (2004). Parental school involvement and childrens academic achievement: Pragmatics and issues. Current Directions in Psychological Science, 13(4), 161-164. Ho, E. S. (2009). Educational leadership for parental involvement in an Asian context: Insights from Bourdieu's theory of practice. The School Community Journal, 19(2), 101-122.

Hornby, G. (2011). Parental involvement in childhood education: Building effective schoolfamily partnerships. New York: Springer.

Hoover Dempsey, K. V., \& Sandler, H. M. (1997). Why do parents become involved in their children's education? Review of Educational Research, 67(1), 3-42.

Izzo, C. V., Weissberg, R. P., Kasprow, W. J., \& Fendrich, M. (1999). A longitudinal study of teacher perceptions of parent involvement in children's education and school performance. American Journal of Community Psychology, 27(6), 817-839.

Johnson, V. R. (1994). Connecting families and schools through mediating structures. The School Community Journal, 4(1), 45-51.

Lee, J., \& Bowen, N. K. (2006). Parental involvement, cultural capital, and the achievement gap among elementary school children. American Educational Research Journal, 43(2), 193-218.

Lindle, J. (1989). What do parents want from principals and teachers? Educational Leadership, 47(2), $12-14$.

Long, C. (2007). Parents in the picture: Building relationships that last beyond back to school night. NEA Today, 3(26), 26-31.

Mattingly, D. J., Prislin, R., McKenzie, T. L., Rodriguez, J. L., Kayzar, B. (2002). Evaluating evaluations: The case of parent involvement programs. Review of Education Research, 72(4), $549-576$.

Murphey, D. A. (1992). Constructing the child: Relations between parents' beliefs and child outcomes. Developmental Review, 12(2), 199-232.

Okagaki, L., \& Frensch, P. A. (1998). Parenting and children's school achievement: A multiethnic perspective. American Educational Research Journal, 35(1), 123-144.

Olioff, M., \& Aboud, F. E. (1991). Predicting postpartum dysphoria in primiparous mothers: Roles of perceived parenting self-efficacy and self-esteem. Journal of Cognitive Psychotherapy, 5(1), 3-14. Rich, D. (1987). Teachers and parents: an adult-to-adult approach. Washington, DC: National Education Association. 
Richardson, S. A. (2009). Principal's perceptions of parental involvement in the "big 8" urban districts of Ohio. Research in the Schools, 16(1), 1-12.

Rumberger, R. W., Ghatak, R., Poulos, G., Ritter, P. L., \& Dornbusch, S. M. (1990). Family influences on dropout behavior in one California high school. Sociology of Education, 63(4), 283-299.

Rutherford, R. B., \& Edgar, E. (1999). Teachers and parents: A guide to interaction and cooperation. Boston: Allyn and Bacon, Inc.

Sanders, M. G. \& Sheldon, S. B. (2009). Principals matter: A guide to school, family, and community partnerships. Corwin: A SAGE Company.

Sheldon, S. B. (2009). In School, family, and community partnerships: Your handbook for action. (3rd ed.). USA: Corwin Press.

Suizzo, M. (2007). Home based parental involvement in young children's education: Examining the effects of maternal education across U.S. ethnic groups. Educational Psychology, 27(2), 1-24. Swap, S. M. (1993). Developing home-school partnerships. New York: Teachers College Press. Turnbull, A., Turnbull, R., Erwin, E. J., Soodak, L.C., \& Shogren, K.A. (2011). Families, professionals and exceptionality. Boston: Pearson.

Weisz, E. (1990). Developing positive staff-parent partnerships in high schools. American Secondary Education, 19(1), 25-28.

Whitaker, T., \& Fiore, D. (2001). Dealing with difficult parents. Larchmont, NY: Eye on Education. Williams, T. T., \& Sanchez, B. (2011). Identifying and decreasing barriers to parent involvement for inner-city parents. Youth \& Society, 45(1), 54-74.

\section{Biographical note}

MAŠA ĐURIšı́́, master teacher, works in Primary school "Veselin Masleša" in Belgrade, Republic of Serbia, also a PhD student of the Faculty of Special Education and Rehabilitation in Belgrade, where she is currently preparing doctoral dissertation. Special topics: the treatment and prevention of behavioural disorders. She wrote a number of research studies and participated in several projects and international conferences.

Mila BuniJevac works as a speech therapist - a vocal therapist in Clinical Hospital "St. Sorcerers" in Bijeljina, Bosnia and Herzegovina. Currently a doctoral candidate at the Faculty for Special Education and Rehabilitation, where she works on her doctoral dissertation. She wrote a number of research studies and is currently participating in the realization of others. 